\title{
Mutant mouse models of autism spectrum disorders
}

\author{
Giovanni Provenzano $^{\mathrm{a}}$, Giulia Zunino ${ }^{\mathrm{a}}$, Sacha Genovesi ${ }^{\mathrm{a}}$, Paola Sgadò ${ }^{\mathrm{a}}$ and Yuri Bozzi ${ }^{\mathrm{a}, \mathrm{b}, *}$ \\ ${ }^{a}$ Laboratory of Molecular Neuropathology, Centre for Integrative Biology, University of Trento, Trento, Italy \\ ${ }^{\mathrm{b}}$ Neuroscience Institute, National Research Council, Pisa, Italy
}

\begin{abstract}
Autism spectrum disorders (ASDs) are a heterogeneous group of neurodevelopmental diseases characterized by a triad of specific behavioral traits: abnormal social interactions, communication deficits and stereotyped or repetitive behaviors. Several recent studies showed that ASDs have a strong genetic basis, contributing to the discovery of a number of ASD-associated genes. Due to the genetic complexity of these disorders, mouse strains with targeted deletion of ASD genes have become an essential tool to investigate the molecular and neurodevelopmental mechanisms underlying ASD. Here we will review the most relevant genetic mouse models developed by targeted inactivation of ASD-associated genes, and discuss their importance for the development of novel pharmacological therapies of these disorders.
\end{abstract}

Keywords: Autism, brain development, knockout mouse, animal model

\section{Introduction}

Autism spectrum disorders (ASD) are a heterogeneous group of brain diseases with a well recognized genetic and neurodevelopmental origin. Due to the complexity of these pathologies, the importance of animal models in ASD research has been widely recognized in recent years. Namely, the generation of mouse strains with targeted deletion of ASD-associated genes has become an essential tool to investigate the neurodevelopmental basis of ASD, as well as the molecular, cellular, anatomical, electrophysiological and behavioural consequences of gene dysfunction in ASD. Several genetic mouse models of ASD have been developed, whose complete phenotypic characterization is still under investigation in several laboratories [21, 116,130]. In this review, we will describe only the most relevant mouse models that were generated by targeted inactivation of ASD-associated genes. ASD-associated genes will be presented following the classification pro-

*Corresponding author: Yuri Bozzi, Laboratory of Molecular Neuropathology, Centre for Integrative Biology (CIBIO), University of Trento, Trento, Italy. Tel.: +39 0461 283651; Fax: +390461 283937; E-mail: bozzi@ science.unitn.it. posed in the SFARIgene database of the Simon Foundation Autism Research Initiative (https://gene.sfari.org): syndromic ASD genes, strong candidate genes and genes with suggestive or minimal evidence of ASD association. Congenic mouse strains showing ASD features, as well as experimentally-induced mouse models will not been discussed in this review. For a comprehensive list of the available mouse models for ASD, the reader is referred to the SFARIgene database (https:// gene.sfari.org).

\section{Syndromic genes}

Syndromic ASD genes are defined as those genes predisposing to autism in the context of a syndromic disorder (e.g. fragile X syndrome) (https://gene.sfari. org). These include CNTNAP2, FMR1, MECP2, NF1, PTEN, SHANK3, TSC1/2 and UBE3A (Table 1).

\subsection{CNTNAP2}

Contactin-associated protein-like 2 (CNTNAP2; also known as CASPR2) is a member of neuronal neurexin superfamily involved in neuron-glia interac- 
Table 1

Mutant mouse models of autism spectrum disorders

\begin{tabular}{|c|c|c|c|c|}
\hline Gene & $\begin{array}{l}\text { SFARI } \\
\text { classification }\end{array}$ & Mouse model & Phenotype & References \\
\hline CNTNAP2 & syndromic & Cntnap $2^{-/-}$mice & $\begin{array}{l}\text { ASD core behavioural symptoms, hyperactivity and seizures, } \\
\text { loss of GABAergic neurons in the cortex, striatum and } \\
\text { hippocampus }\end{array}$ & 118 \\
\hline FMR1 & syndromic & Fmrl KO mice & $\begin{array}{l}\text { Attentional dysfunction } \\
\text { Social anxiety and impaired social cognition } \\
\text { Ultrasound vocalization deficits } \\
\text { Seizures } \\
\text { Reduced expression of } \mathrm{GABA}_{A} \text { receptor subunits } \\
\text { Altered GABAergic transmission } \\
\text { Loss of PV cortical interneurons }\end{array}$ & $\begin{array}{l}112 \\
105,109,134 \\
123 \\
50 \\
2,49 \\
27,43 \\
125\end{array}$ \\
\hline MECP2 & syndromic & $\begin{array}{l}\text { Viaat-Mecp } 2 \text { condi- } \\
\text { tional mutant mice }\end{array}$ & $\begin{array}{l}\text { ASD-like repetitive and stereotyped behaviours, EEG ab- } \\
\text { normalities and seizures, reduced GAD } 65 / 67 \text { mRNA in the } \\
\text { cerebral cortex, decreased cortical miniature inhibitory post- } \\
\text { synaptic currents }\end{array}$ & 29 \\
\hline NF1 & syndromic & $\begin{array}{l}N f 1^{+/-} \text {mice } \\
\text { Mice lacking } N f 1 \text { in } \\
\text { interneurons }\end{array}$ & $\begin{array}{l}\text { Deficits in early-LTP and spatial learning } \\
\text { Over-activation of Ras signaling in inhibitory interneurons dur- } \\
\text { ing learning, abnormal enhancement of GABA release }\end{array}$ & $\begin{array}{l}38,39,131 \\
41\end{array}$ \\
\hline PTEN & syndromic & $\begin{array}{l}\text { Mice lacking Pten in } \\
\text { the cerebral cortex and } \\
\text { hippocampus }\end{array}$ & $\begin{array}{l}\text { Altered social behaviour and inappropriate responses to sensory } \\
\text { stimuli }\end{array}$ & 100 \\
\hline \multirow[t]{3}{*}{ SHANK3 } & \multirow[t]{3}{*}{ syndromic } & Shank3B mutant mice & $\begin{array}{l}\text { ASD-like features (repetitive grooming, reduced social be- } \\
\text { haviours) }\end{array}$ & 117 \\
\hline & & Shank3A mutant mice & $\begin{array}{l}\text { Milder phenotype than Shank } 3 B \text { mice (normal social be- } \\
\text { haviours and reduced recognition of social novelties) }\end{array}$ & 117 \\
\hline & & $\begin{array}{l}\text { Shank3(e4-9) mutant } \\
\text { mice }\end{array}$ & $\begin{array}{l}\text { Abnormal social and repetitive behaviours, impaired learning } \\
\text { and memory }\end{array}$ & 117 \\
\hline TSC1 & syndromic & $T s c 1^{+/-}$mice & $\begin{array}{l}\text { Deficits in learning, memory and contextual fear conditioning, } \\
\text { reduced levels of social exploration }\end{array}$ & 56,68 \\
\hline \multirow[t]{2}{*}{$\mathrm{TSC} 2$} & \multirow[t]{2}{*}{ syndromic } & \multirow[t]{2}{*}{$T s c 2^{+/-}$mice } & $\begin{array}{l}\text { Deficits in learning, memory and contextual fear conditioning, } \\
\text { normal social behaviour, altered ultrasonic vocalization }\end{array}$ & $56,68.153$ \\
\hline & & & $\begin{array}{l}\text { Dowregulation of mGluR } 5 \text { signaling contributes to behavioural } \\
\text { deficits }\end{array}$ & 6 \\
\hline \multirow[t]{2}{*}{ UBE3A } & \multirow[t]{2}{*}{ syndromic } & Ube $3 A^{-/-}$mice & $\begin{array}{l}\text { Impaired motor function, inducible seizures, learning deficits, } \\
\text { abnormal hippocampal EEG and impaired LTP }\end{array}$ & 110 \\
\hline & & $\begin{array}{l}\text { Transgenic mice with } \\
\text { triple dosage of } \\
\text { Ube } 3 A\end{array}$ & $\begin{array}{l}\text { Defective social interaction, impaired communication, and in- } \\
\text { creased repetitive stereotypic behaviour }\end{array}$ & 132 \\
\hline CNTN4 & strong candidate & Cntn $4^{-1-}$ mice & No data available about ASD-like traits & 59 \\
\hline NRXN1 & strong candidate & Nrxnl $<^{-/-}$mice & $\begin{array}{l}\text { Impaired spatial memory, increased repetitive behaviours } \\
\text { Differences in novelty responsiveness in male } \operatorname{Nrxn} 1<^{+/-} \\
\text {mice }\end{array}$ & $\begin{array}{l}15,35 \\
92\end{array}$ \\
\hline \multirow[t]{2}{*}{ EN2 } & \multirow[t]{2}{*}{$\begin{array}{l}\text { suggestive or } \\
\text { minimal evidence }\end{array}$} & \multirow[t]{2}{*}{ En2 ${ }^{-/-}$mice } & $\begin{array}{l}\text { Decreased play, reduced sociality, impaired spatial learning/ } \\
\text { memory }\end{array}$ & 30 \\
\hline & & & $\begin{array}{l}\text { Decreased interneuron connectivity, increased seizure } \\
\text { susceptibility }\end{array}$ & 145 \\
\hline FOXP2 & $\begin{array}{l}\text { suggestive or } \\
\text { minimal evidence }\end{array}$ & Foxp $2^{-/-}$mice & $\begin{array}{l}\text { Motor impairment, absence of ultrasonic vocalizations in pups, } \\
\text { cerebellar defects upon maternal separation }\end{array}$ & 129 \\
\hline GABRB3 & $\begin{array}{l}\text { suggestive or } \\
\text { minimal evidence }\end{array}$ & Gabrb3 $3^{-/-}$mice & $\begin{array}{l}\text { ASD-like traits (reduced sociability, reduced social novelty } \\
\text { testing, attention deficits), learning and memory deficits, poor } \\
\text { motor skills, seizure suscetibility, tremors, hyperactivity, cere- } \\
\text { bellar hypoplasia }\end{array}$ & $42,47,75$ \\
\hline
\end{tabular}


Table 1, continued

\begin{tabular}{|c|c|c|c|c|}
\hline Gene & $\begin{array}{l}\text { SFARI } \\
\text { classification }\end{array}$ & Mouse model & Phenotype & References \\
\hline NLGN1 & $\begin{array}{l}\text { suggestive or } \\
\text { minimal evidence }\end{array}$ & Nlgn1 $1^{-/-}$mice & $\begin{array}{l}\text { Repetitive behaviours, deficits in hippocampus-dependent } \\
\text { learning and memory, decreased hippocampal LTP } \\
\text { Decreased GABAergic activity }\end{array}$ & 35 \\
\hline NLGN3 & $\begin{array}{l}\text { suggestive or } \\
\text { minimal evidence }\end{array}$ & $\begin{array}{l}\text { Nlgn } \\
\text { in mice } \\
\text { Nlgn } 3^{-/-} \text {mice }\end{array}$ & $\begin{array}{l}\text { Increased inhibitory synaptic transmission, deficits in social } \\
\text { interaction } \\
\text { Partial loss of PV-positive basket cells in the cerebral cortex }\end{array}$ & $\begin{array}{l}141 \\
67\end{array}$ \\
\hline NLGN4 & $\begin{array}{l}\text { suggestive or } \\
\text { minimal evidence }\end{array}$ & $N \operatorname{lgn} 4^{-/-}$mice & Abnormalities in reciprocal social interaction & 82 \\
\hline OXT & $\begin{array}{l}\text { suggestive or } \\
\text { minimal evidence }\end{array}$ & $O x t^{-/-}$mice & $\begin{array}{l}\text { Social memory deficits, reduced ultrasonic vocalizations, in- } \\
\text { creased aggression, failure to recognize familiar conspecifics } \\
\text { after repeated social encounters }\end{array}$ & 148 \\
\hline OXTR & $\begin{array}{l}\text { suggestive or } \\
\text { minimal evidence }\end{array}$ & Oxtr ${ }^{-/-}$mice & $\begin{array}{l}\text { Impaired social recognition, reduced ultrasonic vocalization, } \\
\text { increased aggression } \\
\text { Reduced cognitive flexibility and increased seizure } \\
\text { susceptibility }\end{array}$ & 142 \\
\hline RELN & $\begin{array}{l}\text { suggestive or } \\
\text { minimal evidence }\end{array}$ & Reeler mice & $\begin{array}{l}\text { ASD-like behaviours } \\
\text { Disorganized cerebral cortex and cerebellum } \\
\text { Increased seizure susceptibility } \\
\text { Partial loss and unproper positioning of cortical GABAergic } \\
\text { neurons } \\
\text { Decreased GABA turnover }\end{array}$ & $\begin{array}{l}101 \\
44,45 \\
115 \\
71,98,110 \\
150 \\
25\end{array}$ \\
\hline
\end{tabular}

The table reports the most relevant mouse models developed by targeted inactivation of ASD-associated genes, classified according to the criteria proposed by the Simon Foundation Autism Research Initiative (SFARI; https://gene.sfari.org). For a comprehensive list of ASD mouse models see https://gene.sfari.org and references in [130]. Abbreviations are as in the text.

tions, neuronal migration in the developing cortex and clustering of voltage-gated K channels at Ranvier's nodes [120,136]. Originally, CNTNAP2 was linked to the cortical dysplasia-focal epilepsy syndrome, a rare disorder characterized by cortical dysplasia, focal epilepsy and autism [136]. Subsequently, genetic studies provided additional evidence that rare and common variants of this gene may contribute to ASD or ASDrelated endophenotypes [3,5,7]. Interestingly, speechlanguage impairment frequently occurs as a phenotype of people with polymorphisms in CNTNAP2. Moreover, the expression of this gene can be regulated by FOXP2, whose mutations lead to language and speech disorders [146]; see below, Section 4.2). Deletion of Cntnap 2 in mice results in core behavioural symptoms of ASD (stereotypic behaviours, social interactions and vocal communication) [118]. Cntnap $2^{-/-}$mice also show hyperactivity and seizures, both features often associated with ASD patients [133]. Administration of risperidone (the first FDA drug approved for ASD treatment) ameliorates hyperactivity and repetitive behaviours but not social deficits in Cntnap2-/mice. Neuropathological analyses revealed abnormal neuronal distribution in deep cortical layers postnatal day (P) 7 and adult Cntnap $2^{-/-}$mice, and presence of ectopic neurons in the corpus callosum of mutant mice at P14. Interestingly, Cntnap $2^{-/-}$mice display a reduced number of GABAergic interneurons in the cortex, striatum and hippocampus. Moreover, in vivo two-photon calcium imaging showed that Cntnap $2^{-/-}$ mice exhibit reduced cortical neuronal synchrony with respect to wild-type (WT) mice, an interesting finding considering that these abnormalities are similar to those seen in many people with ASD [118].

\subsection{FMRI}

Fragile X syndrome (FXS) is the most frequent inherited cause of mental retardation and an identified cause of autism [52]. The Fragile Mental Retardation 1 locus (FMR1) resides in the $\mathrm{X}$ chromosome. FXS results from the expansion of triplet repeats in the untranslated region of the FMR1 gene, preventing synthesis of the FMR1 gene product FMRP. FM$\mathrm{RP}$ is a RNA-binding protein that modulates mRNA trafficking, dendritic maturation and synaptic plasticity [154]. The phenotype of Fmrl knockout (KO) mice has been extensively studied [13,108]. Fmrl KO mice show a complex behavioral profile, characterized by a number of ASD-like symptoms, including attention dysfunction [112], social anxiety and impaired social cognition [105,109,134], ultrasound vocalization 
deficits [123] and seizures [150]. ASD-like features in Fmrl KO mice are dependent on the mouse genetic background $[119,135]$. These altered behaviors are accompanied by a series of anatomical and synaptic plasticity deficits, mainly affecting neurotransmission at the level of $\mathrm{GABA}_{A}$ and group I metabotropic glutamate (mGluR1/5) receptors. Several studies showed a severe reduction in the expression of $\mathrm{GABA}_{A}$ receptor subunit mRNAs and proteins in adult Fmrl KO mice [2,49], along with an abnormal GABAergic transmission [27, 43] and deficits of parvalbumin (PV) expressing cortical GABAergic interneurons [125]. A "metabotropic glutamate receptor (mGluR) theory" of FXS pathogenesis has also been proposed, based on a series of findings indicating that in the absence of FMRP, the FMRP-dependent consequences of mGluR5 activation are exaggerated [10]. In agreement with this hypothesis, Fmrl KO with a $50 \%$ reduction of mGlur5 (obtained by crossing Fmrl mutant mice with Grm5 mutant mice) showed a complete rescue of anatomical, plasticity and behavioral deficits [50]. These findings led to propose mGlur5 as a pharmacological target for the cure of FXS and ASD (see also Section 5.1).

\section{3. $M E C P 2$}

Rett syndrome (RTT) is an X-linked neurodevelopmental disorder typically emerging between 618 months of age characterized by the progressive loss of cognitive and motor functions, the emergence of ASD-like features and the occurrence of epileptic seizures [28]. RTT is caused by mutations in the gene encoding for the methyl-CpG binding protein 2 (MECP2), a transcriptional regulator involved in chromatin remodeling and splicing. Mice with truncated $\mathrm{MeCP} 2$ recapitulate many RTT features [23,32,70,126] and activation of the $\mathrm{MeCP} 2$ protein even at late stages of the disease can rescue the mutant phenotype [5, 64]. With respect to typical ASD features, the most interesting data were recently obtained in conditional mutants lacking Mecp2 in inhibitory neurons expressing Viaat (Vesicular inhibitory aminoacid transporter, required to load GABA and glycine into synaptic vesicles) [29]. Viaat-Mecp 2 conditional mutants exhibit ASD-like repetitive and stereotyped behaviours, accompanied by electroencephalographic (EEG) abnormalities and seizures. Viaat-Mecp 2 conditional mutants show reduced levels of glutamic acid decarboxylase (GAD65/67) mRNA in the cerebral cortex, as well as decreased miniature inhibitory post-synaptic currents (mIPSC) in cortical slices, suggesting that Mecp2 deficiency in GABAergic neurons might determine a reduction of GABA release as a consequence of reduced GAD synthesis in presynaptic terminals [29]. This study indicates that loss of Mecp 2 in inhibitory neurons might be a crucial determinant of severe forms of ASD.

\subsection{NF1}

Neurofibromatosis type 1 (NF1) is a neurocutaneous disorder caused by mutations in the NF1 gene [36, 55]. The NF1 gene encodes for a protein called neurofibromin, a GTPase activator involved in the regulation of the Ras/ERK signaling [8,102]. In patients, NF1 is frequently associated with intellectual and learning deficits [114,127], and a greater susceptibility to autism $[103,104]$. In mice, the complete loss of Nf1 is lethal, due to embryonic heart malformations [17, 79]. $\mathrm{NII}^{+/-}$mice are instead viable and show deficits in the early phase of long-term potentiation (LTP), as well as compromised spatial learning in the Morris water maze $[38,39,41,131]$. Interestingly, mice with $N f 1$ deletion restricted to inhibitory neurons develop normally, do not show tumor predisposition but display learning deficits in the adult life [41]. Using these mice a cellular mechanism underlying Nf1-dependent learning deficits has been proposed, in which $N f 1$ deficiency can lead to an over-activation of Ras signaling in inhibitory interneurons during learning, resulting in abnormal enhancement of GABA release from these neurons [41]. Spatial learning deficits and LTP can be rescued in $\mathrm{NI}^{+/}$- mice by using pharmacological/genetic approaches that inactivate Ras-ERK signaling or decrease GABA-mediated inhibition [39,41,97] (see also Section 5.4).

\subsection{PTEN}

The tumor suppressor Phosphatase and Tensin homolog on chromosome 10 (PTEN) is a negative regulator of the phosphatidylinositol 3-kinase (PI3K) signaling pathway, which mediates several processes in various tissues. PTEN is a phosphatase that dephosphorylates the second messenger phosphatidylinositol$(3,4,5)$-trisphosphate (PIP3) in phosphatidylinositol(4,5)-disphosphate (PIP2), reducing the activity of the protein kinases AKT/PKB and its downstream signaling cascade. AKT kinases can act on a large spectrum of substrates, including tuberous sclerosis complex 2 (TSC2/Tuberin; see Section 2.7), glycogen synthase kinase $3 \beta(\mathrm{GSK} 3 \beta)$, and the proapoptotic protein 
BAD [100]. Mutations in the PTEN induce Cowden syndrome, characterized by prostate, skin and colon defects, spontaneous tumors and neurologic features such as autism and Lhermitte Duclos disease [147]. PTEN mutations have been reported in autistic individuals with macrocephaly $[20,66,157]$. In mice, conditional deletion of Pten in limited differentiated neuronal populations of the mouse cerebral cortex and hippocampus leads to abnormal dendritic and axonal growth, increased synapse number, neuronal hypertrophy and macrocephaly. Pten conditional mutant mice exhibit altered social behavior and inappropriate responses to sensory stimuli [100].

\subsection{SHANK3}

Shank family proteins (Shank1-3) are multidomain scaffold proteins forming the postsynaptic density complexes (PSD). Shank proteins have an important role to physically connect neurotransmitter receptors and other membrane proteins to actin cytoskeleton and signaling effectors in dentritic spines, contributing to synapse formation and spine maturation [90]. The functional importance of Shank scaffolding proteins is revealed by the fact that many mutations in Shank genes induce forms of mental retardation. Several studies found a correlation between ASD and single mutations in Shank3 [53,63,111]. Two Shank3 mutant mice strains have been generated, named Shank3A and Shank3B [117]. In Shank3A mutant mice, the Shank $3 \alpha$ isoform was completely eliminated, whereas in Shank3B mutants both Shank3 isoforms were deleted, also comprising a putative $3 \gamma$ isoform. Shank $3 B$ mutants show ASD-like features, such as repetitive grooming and reduced social behaviors. Striatal hyperthrophy and reduced cortico-striatal glutamatergic transmission is also observed in these mutants. Shank3A mutant mice display a milder phenotype than Shank3B mice, characterized by a normal social behaviors and reduced recognition of social novelties [117]. Shank3(e4-9) mutant mice bear a deletion of exons 4 to 9 . These mice display abnormal social and repetitive behaviors, as well as also impaired learning and memory. These behavioral deficits are accompanied by alterations in dendritic spines and impaired LTP [117]. Other studies shed light on the importance of Shank3 interactions with the scaffolding protein Homer; indeed, mutations affecting the Shank3-Homer binding site have been associated to ASD [53]. Heterozygous mice for a deletion of the Shank3-Homer binding site at the $\mathrm{C}$ terminus (Shank3 $+/ \Delta C$ mice) display a $>90 \%$ reduction of Shank3 expression at synapses, reduced NMDAR-dependent synaptic responses in the frontal cortex and reduced social behaviors; Shank $3+/ \Delta C$ mice show no changes in synapse number and morphology, and normal learning and memory abilities [9].

\section{7. $T S C 1 / 2$}

Tuberous Sclerosis Complex (TSC) is a neurocutaneous syndrome characterized by benign tumors, early onset epilepsy, intellectual disability, and autism [74]. TSC results from loss-of-function mutations of TSC1 or TSC2 genes, which are crucially involved in the control of neuronal and glial cell proliferation during embryonic development. TSC1 encodes a protein (hamartin) containing two coiled-coil domains, while TSC2 encodes a GTPase activating protein (tuberin) that inhibits small G-proteins belonging to the Rasrelated super-family. Hamartin and tuberin are both expressed in neurons and astrocytes of specific central nervous system (CNS) regions such as forebrain, cerebellum and brainstem, where they form a proteinprotein complex that constitutively inhibits mTOR (mammalian target of rapamycin). Loss of TSC1/2 function leads to activation of the mTOR cascade and results in increased cell proliferation [74,86]. Mice with a heterozygous inactivating mutation in the Tsc genes $\left(T s c 1^{+/-}\right.$and $T s c 2^{+/-}$mice) show deficits in learning, memory and contextual fear conditioning $[56,68]$. In addition to learning and memory deficits, $T s c 1^{+/-}$ mice have reduced levels of social exploration, while $T s c 2^{+/-}$knockout mice show a normal social behavior $[68,128]$ but altered ultrasonic vocalization [153]. In addition to behavioral changes, synaptic abnormalities are observed in the hippocampus of $T s c 2^{+/-}$and in mice with a conditional homozygous deletion of Tsc1 in astrocytes [56,68]. Furthermore, Tsc1 conditional knockout mice show abnormal dendritic spine morphology and density, enhanced cortical excitability and seizures $[143,106]$. In contrast with the main feature of human disease, $T s c 1^{+/-}$or $T s c 2^{+/-}$mice do not develop tubers $[16,56,68,89]$, indicating that anatomical lesions are not involved in the pathogenesis of learning and social deficits. Recent studies also indicate that a dowregulation of mGluR5 signaling can contribute to synaptic and behavioural deficits in $T s c 2^{+/-}$mice [6] (see also Sections 2.2 and 5.1). Taken together, these findings are interesting in light of the high prevalence of ASD in human TSC populations, pointing out the potential role of Tsc genes in the pathogenesis of syndromic ASD. 


\section{8. $U B E 3 A$}

Angelman syndrome is a neurodevelopmental disorder characterized by mental retardation, absence of language development, EEG abnormalities and epilepsy. The genetic defects underlying Angelman syndrome are heterogeneous, including large maternal deletions of chromosome 15q11-q13, disomies of chromosome 15 and mutations in the E6-AP ubiquitin ligase gene UBE3A, located on chromosome 15 [84,88]. In mice, $U b e 3 a$ is required for experience-dependent maturation of the neocortex [152] and a deficiency of the maternal allele of $U b e 3 a$ results in impaired motor function, inducible seizures, learning deficits, abnormal hippocampal EEG and severely impaired LTP [110]. Increased gene dosage of Ube 3 a results in ASD-like traits and decreased glutamate synaptic transmission in mice. These results suggest that $U b e 3 a$ gene dosage may contribute to the autism traits of individuals with maternal 15q11-13 duplication [132].

\section{Strong candidate genes}

Strong ASD candidate genes are defined as those genes for which a rigorous statistical comparison between cases and controls has been performed in a series of independent studies, yielding genome-wide statistical significance of ASD association (categories 1 and 2 in the SFARIgene database; https://gene.sfari.org). These include CNTN4 and NRXN1 (Table 1).

\subsection{CNTN4}

Several rare variants have been described in the CNTN4 gene in association with neurodevelopmental disorders including ASD [59,122]. Contactin4 (CNTN4), also known as BIG2 (brain-derived immunoglobulin superfamily molecule 2), is an axonal cell adhesion molecule that belonging to the contactin family. CNTN4 is mainly expressed in the brain (cerebellum, thalamus, amygdala, and cerebral cortex) where it is thought to play an essential role in the formation of axonal connections during development [59]. No data are available regarding the presence of ASDlike traits in mice lacking Cntn4. Cntn $4^{-/-}$mice display aberrant projection of olfactory sensory neurons to multiple glomeruli, suggesting that Cntn4 is an axon guidance molecule required for establishment of the olfactory neural circuitry [87]. Interestingly, several studies have shown olfactory deficits in a range of psychiatric and neurodevelopmental disorders including schizophrenia and ASD [12,18,37,138].

\section{2. $N R X N 1$}

Neurexins (NRXNs) are presynaptic cell adhesion proteins that form trans-synaptic cell-adhesion complexes with their postsynaptic counterpart neuroligins (NLGNs) [137]. The interaction between neuroligins and neurexins is controlled by alternative splicing of both neuroligin and neurexin genes $[33,40]$. There are three NRXN genes in mammals, NRXN1-3, each expressed as a long $\alpha$ - and a short $\beta$-isoform by two alternative promoters. NRXNs are localized presynaptically, and their distribution to excitatory or inhibitory synapses is regulated by alternative splicing[40]. Rare single gene variations in the NRXN1 gene have been found associated with autism [57,139]. Mice with a targeted deletion of the promoter and first exon of Nrxn1 $\alpha$ show a complete loss of Nrxn $1 \alpha$ protein but unaltered levels of Nrxn $1 \beta$ and can therefore be considered as a Nrxn $1 \alpha$ knockout. Nrxn $1 \alpha$ deletion results in electrophysiological changes, impaired spatial memory and increased repetitive behaviors, traits that are all consistent with cognitive impairments $[15,35]$. Interestingly, Nrxn $1 \alpha^{+/-}$mice show differences in novelty responsiveness that are observed only in male mice, indicating sex-specific differences of the behavioral phenotype [92].

\section{Genes showing suggestive or minimal evidence of ASD association}

Genes with suggestive or minimal evidence of ASD association are defined as those candidate genes for which only small/unreplicated genetic studies have been performed (categories 3 and 4 in the SFARIgene database; https://gene.sfari.org). These include EN2, FOXP2, GABRB3, NGLNs, OXT/OXTR and RELN (Table 1).

\subsection{EN2}

EN2 codes for the homeobox-containing transcription factor Engrailed-2, a key regulator of posterior brain (midbrain/hindbrain) embryonic development [85]. The human EN2 gene maps to a region of chromosome 7 implicated in ASD susceptibility, and genome-wide association (GWA) studies indicated EN2 as a candidate gene for ASD. Namely, two SNPs in the human EN2 gene have been associated to ASD, one of which (rs1861973, A-C haplotype) is functional: when tested in a luciferase reporter assay 
in rat, mouse and human cell lines, this SNP markedly upregulates EN2 promoter activity [11]. Preliminary evidence indicate that the EN2 A-C haplotype is also functionanal in vivo, being able to upregulate reporter gene expression in transgenic mice [34]. En2 $2^{-/-}$ mice display cerebellar hypoplasia and a reduced number of Purkinje cells [85]. Importantly, ASD-like behaviours (decreased play, reduced sociality, impaired spatial learning and memory) were described in these mutants [30]. Recently we showed that En2 is also expressed in the adult hippocampus and cerebral cortex; $E n 2^{-/-}$mice also show an increased susceptibility to experimentally-induced seizures that is accompanied by altered GABAeregic connectivity in the hippocampus (namely, reduced PV staining on cell bodies of CA3 pyramidal neurons and reduced somatostatin staining in the stratum lacunosum moleculare). We proposed that $E n 2^{-/-}$mice might be used as model to study the role of GABAergic system dysfunction in the genesis of autism and epilepsy [145].

\section{2. $F O X P 2$}

FOXP2 is a transcription factor containing a polyglutamine tract and a forkhead DNA-binding domain. Heterozygous mutations of the FOXP2 gene in humans cause severe speech and language disorders $[60,93,94]$. FOXP2 was recently associated to ASD by homozygous haplotype mapping [26]. While FOXP2 mutations were not directly associated to increased ASD risk, the language dysfunction that is central to ASD diagnosis may be influenced by FOXP2, therefore the FOXP2 gene has been considered as a potential autism susceptibility gene [61]. FOXP2 is expressed in multiple regions within the developing brain including the cortical plate, basal ganglia, thalamus, inferior olive, and cerebellum. Foxp $2^{-/-}$mice show severe motor impairment, premature death, and an absence of ultrasonic vocalizations in pups upon maternal separation [129]. Histological analyses of these mice suggest that Foxp2 mutation influences neuronal migration and/or maturation in the developing cerebellum [129]. Foxp $2^{+/-}$ mice show reduced synaptic plasticity of cortico-striatal circuits, associated with deficits in learning of rapid motor skills [69]. These motor deficits are consistent with the observed cerebellar phenotype, suggesting that the language dysfunction in these mice is due merely to motor function deficits [129]. However, recent studies have revealed novel cognitive deficits in Foxp $2^{-/-}$ mice that go beyond motor functions and extend to auditory-motor association learning [91]. The analysis of FOXP2 transcriptional targets identified a FOXP2bound fragment in the first intron of another ASD candidate gene, CNTNAP2 (see Section 2.1). Further experiments confirmed that FOXP2 downregulates CNTNAP2 expression, strengthening the link between FOXP2 function and ASD [60,146].

\section{3. $G A B R B 3$}

The Angelman susceptibility region of chromosome $15 q 11$ (see section 2.8) also contains the genes coding the $\mathrm{GABA}_{A}$ receptor subunits $\alpha 5, \beta 3$ and $\gamma 3$ (GABRA5, GABRB3 and GABRG3, respectively); SNPs in these genes have been associated to ASD [73, 135]. Gabrb3 $3^{-/-}$mice display high mortality rate, learning and memory deficits, poor motor skills, seizure suscetibility, tremors, hyperactivity and cerebellar hypoplasia $[42,47,75]$. Gabrb3 $3^{-/-}$mice also show a series of ASD-like traits, including reduced sociability and reduced social novelty testing. These mice also display deficits across many attentional domains, including selective and sustained attention with the inability to shift and orient attention rapidly and accurately among spatial targets and between sensory modalities, as compared to WT mice [47]. These observations provide support for the face validity of the Gabrb3-/mouse as a model of ASD.

\subsection{NLGN1, 3 and 4}

There are five known isoforms of the neurexin ligands neuroligins (NLGNs; see also section 3.2) in humans: NLGN1, NLGN2, NLGN3, NLGN4X and NLGN4Y [137]. Genetic association to ASD has been found for three of them: copy number variations in the NLGN1 gene and rare mutations in the NLGN34 genes [82]. In rodents, only four NLGNs exist (NLGN1-4), showing different synaptic localization: NLGN1 is localized exclusively to excitatory synapses, NLGN2 and 4 to inhibitory synapses NLGN3 to both inhibitory and excitatory synapses $[19,76,95]$. The effects of the targeted deletion of all NLGNs has been extensively studied in mice. With the exception of Nlgn2-/- mice, all Nlgn mutant mice show some ASDlike traits. $N \operatorname{lgn} 1^{-/-}$mice display repetitive behaviors, deficits in hippocampus-dependent learning and memory and decreased hippocampal LTP [35]. Recent studies also demonstrate that loss of Nlgnl leads to a small but significant reduction in NRXNs levels in the brain, decreased GABAergic/glycinergic activity and reduced glutamatergic activity [16]. Mice bear- 
ing the R451C mutation found in the human NLGN3 gene $\left(N \operatorname{lgn} 3^{R 451 C}\right.$ knock-in mice) show an increased inhibitory synaptic transmission without a change in excitatory transmission followed by a de?cit in social interaction [141]. Mice with a targeted deletion of Nlgn3 (Nlgn $3^{-/-}$mice) show a partial loss of PV-positive basket cells in the cerebral cortex [67]. Finally, Nlgn4-/mice display abnormalities in reciprocal social interaction but they do not display repetitive behavior or impairments in other ASD-like symptoms such as sensory sensitivity, locomotion, exploratory activity, anxiety, or learning and memory [83].

\subsection{OXT and OXTR}

Oxytocin (OXT) is a nine-amino-acid peptide synthesized in the hypothalamus and released into the bloodstream through axon terminals in the neurohypophysis. Oxytocin stimulates uterine contraction during labor and milk ejection during nursing, and is involved in the central mediation of attachment behavior [77]. OXT effects are mediated by the OXT receptor (OXTR), a seven transmembrane rhodopsin-type Gprotein coupled receptor. OXTRs are found in uterus and mammary tissue, but also in several regions of the brain including the hypothalamus, hippocampus, limbic and autonomic areas $[65,78]$. Reduced OXT plasma levels are observed in autistic children, and OXTR mRNA is decreased in postmortem samples of temporal cortex from ASD patients [78]. Conversely, intranasal infusion of OXT reduces stereotypic behavior and improves eye contact and social memory in autistic patients [4]. Genetic variations in OXTR have been associated with autism $[24,54,80,149]$. Mice with targeted deletion of the oxytocin $(O x t)$ or oxytocin receptor $(O x t r)$ gene have been generated, and their behaviour analyzed with respect to the presence of ASDlike traits. $O x t^{-/-}$mice have selective deficits in social memory. $O x t^{-/-}$pups emit fewer ultrasonic vocalizations upon maternal separation and $O x t^{-/-}$adults are more aggressive than WT mice. Furthermore, $\mathrm{Oxt}^{-/-}$ mice fail to recognize familiar conspecifics after repeated social encounters, despite olfactory and non-social memory functions appear to be intact [148]. Oxtr-/mice show severe impairments in social recognition, reduced ultrasonic vocalization of pups upon maternal separation and increased aggression [142]. In addition, $\mathrm{Oxtr}^{-/-}$mice have reduced cognitive flexibility and increased seizure susceptibility [124]. Interestingly, all these deficits can be rescued by pharmacological administration of oxytocin [124].

\subsection{RELN}

The RELN gene codes for the extracellular matrix glycoprotein Reelin, which is involved in neuronal migration and lamination of the cerebral cortex during embryogenesis [62]. RELN maps to 7q22 human chromosome, a region linked to ASD [131]. Mice lacking Reelin (reeler mice) show a dramatic impairment of migration of cortical projection neurons, that results in a highly disorganized and dyslaminated cerebral cortex [44,45] and epileptiform activity [115]. Reeler mice also show deficits of the GABAergic system, namely decreased number of GAD67-positive cortical neurons [98] decreased GABA turnover [25] and improper layer positioning of GABAergic interneurons in the mature cerebral cortex [71,150]. Recently, ASD-like behaviors and loss of PV interneurons has also been reported in reeler mice [101].

\section{Exploiting animal models for finding a cure}

While knowledge grows about the pathophysiological mechanisms underlying the susceptibility to ASD, mouse models offer powerful translational systems for discovering therapeutic treatments. Early behavioral interventions are currently the only treatments that significantly improve core autistic symptoms (social interactions and communication deficits) $[46,121]$. Current medications only affect secondary symptoms such as hyperactivity or mood, but have not shown any effect on the core features of ASD. Preclinical studies have been reported for genetic and pharmacological rescue of "autistic-like" phenotypes in mouse models of ASD. Here we will summarize the most significant results in preclinical drug testing using ASD mouse models. As summarized in Table 2, successful drug candidates include mGluR5 modulators, growth factors, rapamycin, statins and oxytocin.

\section{1. mGlu5 receptor modulators}

A study of synaptic plasticity in the hippocampus and visual cortex of Fmrl KO mice suggested a novel connection between mGluR signaling and the FXS phenotype (the so-called "mGluR theory" of FXS pathogenesis; see also Section 2.2). In particular, the absence of FMRP was shown to cause an upregulation of mGluR5-mediated signaling. These findings indicated that many aspects of the phenotype of Fmrl KO mice, including behavioural abnormalities, cog- 
Table 2

Pharmacological treatments tested in mouse models of autism spectrum disorders

\begin{tabular}{|c|c|c|c|}
\hline Drug & Mouse models & Effect & References \\
\hline mGlur5 antagonists & Fmrl KO mice & $\begin{array}{l}\text { Reverted multiple phenotypes (including ASD-like } \\
\text { behaviours) }\end{array}$ & $\begin{array}{l}48,140,144, \\
151\end{array}$ \\
\hline mGlur5 agonists & $T s c 2^{+/-}$mice & $\begin{array}{l}\text { Rescue of decreased hippocampal LTD and ASD-like } \\
\text { behaviours }\end{array}$ & 6 \\
\hline BDNF & Fmrl KO mice & $\begin{array}{l}\text { Reducing BDNF expression ameliorates locomotor hyperac- } \\
\text { tivity and deficits in learning and auditory responses }\end{array}$ & $31,113,135$ \\
\hline \multirow[t]{4}{*}{ Rapamycin } & $\begin{array}{l}\text { Neural-specific Pten condition- } \\
\text { al KO mice }\end{array}$ & $\begin{array}{l}\text { Reverted anatomical defects, reduced seizure frequency/ } \\
\text { duration, improved social interaction }\end{array}$ & 156 \\
\hline & Mice lacking $T s c 1$ in neurons & Improved survival rate and rescued neuronal morphology & 106 \\
\hline & Mice lacking $T s c l$ in glial cells & Prevented EEG abnormalities and seizures & 155 \\
\hline & $T s c 2^{+/-}$mice & $\begin{array}{l}\text { Reverted synaptic plasticity and learning/memory deficits in } \\
\text { adult mice (short-term treatment) }\end{array}$ & 56 \\
\hline Statins & $N f 1^{+/}-$mutant mice & Reverted learning/memory deficits & 39,97 \\
\hline \multirow[t]{2}{*}{ Oxytocin } & $O x t^{-/-}$mice & Rescued social recognition deficits & 58 \\
\hline & $O x t r^{-/-}$mice & Rescued ASD-like traits and cognitive deficits & 124 \\
\hline Risperidone & Cntnap $2^{-/-}$mice & Reverted ASD-core symptoms & 118 \\
\hline
\end{tabular}

The table reports novel pharmacological treatments (except risperidone, which is the only FDA-approved drug for ASD) tested in ASD mutant mouse models. Abbreviations are as in the text.

nitive deficits and dendritic spine changes, could be attributable to excessive mGluR5 signaling and could therefore be rescued through genetic downregulation of mGluR5 expression [50]. Indeed, several studies showed that a reduced mGluR5 signaling reversed some of the symptoms in Fmr1 KO mice [50,51]. Pharmacological treatment with mGluR5 negative modulators (MPEP, fenobam, AFQ056, and STX107) was effective in reversing multiple phenotypes in Fmr1 KO mice mouse models $[48,140,144,151]$. These results provided a rationale for developing mGluR5 antagonists as therapeutics. Fenobam was the first negative mGluR5 modulator tested in patients with FXS [14,93] and a phase II double-blind placebo-controlled trial of AFQ056 has been recently conducted in Europe with promising results [81]. More recently, a study performed in $T s c 2^{+/-}$and Fmrl $\mathrm{KO}$ mice highlighted a more complex role of mGluR5 signaling in the pathogenesis of syndromic ASD. Tsc2 and Fmrl mutations result in opposite hippocampal synaptic dysfunction in mice: increased long-term depression (LTD) in Frm 1 KO mice $v s$. decreased LTD in $T s c 2^{+/-}$mice. Interestingly, treatments that modulate mGluR5 signaling in opposite directions are able to correct synaptic defects in these mutants [6], thus raising the possibility to use mGluR5 agonists (positive allosteric modulators) to revert ASD symptoms in TSC.

\subsection{Brain-derived neurotrofic factor (BDNF)}

Several studies suggest a correlation between BDNF signaling and the pathogenesis of FXS. Altered BDNF expression and signaling has been detected in the Fmrl KO mouse brain [99]. More importantly, locomotor hyperactivity and deficits in learning and auditory responses were ameliorated by reducing BDNF expression in Fmrl KO mice [31,113,135]. These results suggest that behavioural abnormalities syndromic ASD could be due to increased BDNF signalling and could theoretically be counteracted by reducing extracellular BDNF levels. Further investigation in models different than Fmrl KO mice is needed to strengthen this hypothesis.

\subsection{Rapamycin}

The mTOR inhibitor rapamycin has been proven to partially revert ASD-ike symptoms in mice with targeted deletion of $T s c 1 / 2$ or the TSC positive regulator PTEN. In neural-specific Pten conditional KO mice, rapamycin was shown to revert anatomical defects, reduce seizure frequency and duration, and improve social interaction [156]. Postnatal rapamycin treatment was also effective in improving the survival rate and rescuing neuronal morphology in mice lacking $T s c 1$ in neurons [107], and preventing seizures and EEG abnormalities in mice lacking Tscl in glial cells [155]. Finally, a short-term (5 days) rapamycin treatment has been shown to revert synaptic plasticity and learning and memory deficits in adult $T s c 2^{+/-}$mice [56]. These studies indicate that pharmacologically interfering with the PTEN-TSC-mTOR pathway via rapamycin admin- 
istration partially ameliorates ASD-like freatures in mice. However, it remains to be clarified whether these achievements in mouse models may translate to therapy in human syndromic ASD patients. In particular, it must be considered that long-term rapamycin treatment is extremely problematic in humans due to its immunosuppressive effects. Novel drugs alternative to rapamycin should be therefore developed.

\subsection{Statins}

Studies performed in Nf1 mutant mice indicate that memory and attention deficits result from Ras pathway activation following $N f 1$ deficiency (see Section 2.4). For these reasons, much emphasis has been given to the potential pharmacological effects derived from inhibition of Ras-mediated signaling in NF1 patients with cognition deficits. In fact, a number of studies in recent years have shown that lovastatin (a drug belonging to the statin class which inhibits GTPases including Ras), can reverse the physiological and behavioral phenotypes of $\mathrm{Nf1}^{+/-}$mutant mice $[39,97]$. Statins are a class of relatively safe drugs used for the treatment of hypercholesterolemia. Another statin (simvastatin) has been shown to improve learning and memory deficits in a transgenic mouse model of Alzheimer's disease [96]. According to these results, preliminary findings in human patients suggest that lovastatin may be able to reverse some of the cognitive deficits in children with NF1 [1]. However, it is important to point out that further study and replication are required to confirm the potential effect of statins for the treatment of cognitive dysfunctions in humans.

\subsection{Oxytocin}

Oxytocin administration has been proven to rescue social recognition deficits in $O x t^{-/-}$mice [58] as well as cognitive deficits in $O x t r^{-/-}$mice [124].

\section{Conclusions and future perspectives}

In this review, we described the most relevant features of mice with targeted inactivation of ASDassociated genes (summarized in Table 1). Several considerations can be drawn from the comparative analyses of these models.

i) Different models show different type of ASDlike symptoms. This is due to genetic heterogen- eity of the disease, and the difficulty of reproducing complex human disorders in mice. However, the use of each of these models is a powerful tool to unravel the contribution of each single gene to ASD.

ii) A careful, standardized phenotypic analysis of the different ASD mouse models is needed, with specific attention to standardized behavioral phenotyping of ASD "core symptoms" (social interactions, communication deficits and repetitive behaviors) [130]. A standardized approach would be of extreme importance for novel drug testing.

iii) The embryonic phenotype as well as the differences among young and adult animals should be carefully evaluated in all the available models, in order to carefully understand the neurodevelopmental basis of ASD. So far, these types of studies have been performed only in a limited number models.

iv) A careful investigation of the CNS transcriptome/proteome should be performed in the different models. These analyses should allow a better characterization of the molecular consequences of ASD gene dysfunction.

v) Cellular, anatomical and functional defects of the GABAergic interneurons are detected in many of the reported strains, indicating a possible role of these neurons in the pathogenesis of ASD.

vi) As a possible consequence of GABAergic dysfunction, seizures often occur in most of these models, reflecting the co-morbidity (and a possible common cause) of ASD and epilepsy.

Most importantly, a number of preclinical studies on ASD mouse models contributed to unravel novel drug candidates for the cure of ASD, including mGluR5 modulators, rapamycin, BDNF, statins and oxytocin (Table 2), thus confirming the relevance of this approach in translational ASD research.

\section{Acknowledgements}

P.S. is a postdoctoral fellow supported by Provincia Autonoma di Trento (Italy) under the Marie CuriePeople cofunding action of the European Community. This work was funded by the Italian Ministry of University and Research (PRIN 2008 grant \# 2008 94SYW2_002) and the University of Trento (CIBIO start-up) grants to Y.B. 


\section{References}

[1] M.T. Acosta, P.G. Kardel, K.S. Walsh, et al., Lovastatin as treatment for neurocognitive deficits in neurofibromatosis type 1: Phase I study, Pediatric Neurology 45 (2011), 241245.

[2] D.C. Adusei, L.K. Pacey, D. Chen, et al., Early developmental alterations in GABAergic protein expression in fragile $\mathrm{X}$ knockout mice, Neuropharmacology 59 (2010), 167-171.

[3] M. Alarcón, B.S. Abrahams, J.L. Stone, et al., Linkage, association, and gene-expression analyses identify CNTNAP2 as an autism-susceptibility gene, Am J Human Genet 82 (2008), 150-159.

[4] E. Andari, J. Duhamel, T. Zalla, et al., Promoting social behavior with oxytocin in high-functioning autism spectrum disorders, Proc Natl Acad Sci U S A 107 (2010), 4389-4394.

[5] D.E. Arking, D.J. Cutler, C.W. Brune, et al., A common genetic variant in the neurexin superfamily member CNTNAP2 increases familial risk of autism, Am J Human Genetics $\mathbf{8 2}$ (2008), 160-164.

[6] B.D. Auerbach, E.K. Osterweil and M.F. Bear, Mutations causing syndromic autism define an axis of synaptic pathophysiology, Nature 480 (2011), 63-68.

[7] B. Bakkaloglu, B.J. O'Roak, A. Louvi, et al., Molecular cytogenetic analysis and resequencing of contactin associated protein-like 2 in autism spectrum disorders, Am J Human Genet 82 (2008), 165-173.

[8] R. Ballester, D. Marchuk, M. Boguski, et al., The NF1 locus encodes a protein functionally related to mammalian GAP and yeast IRA proteins, Cell $\mathbf{6 3}$ (1990), 851-849.

[9] M.A. Bangash, J.M. Park, T. Melnikova, et al., Enhanced polyubiquitination of Shank3 and NMDA receptor in a mouse model of autism, Cell 145 (2011), 758-772.

[10] M.F. Bear, K.M. Huber and S.T. Warren, The mGluR theory of fragile X mental retardation, Trends Neurosci 27 (2004), 370-377.

[11] R. Benayed, J. Choi, P.G. Matteson, et al., Autism-associated haplotype affects the regulation of the homeobox gene, ENGRAILED 2, Biol Psychiatry 66 (2009), 911-917.

[12] L. Bennetto, E.S. Kuschner and S.L. Hyman, Olfaction and taste processing in autism, Biol Psychiatry 62 (2007), 10151021.

[13] M. Bernardet and W.E. Crusio, Fmr1 KO Mice as a Possible Model of Autistic Features, Scientific World Journal 6 (2006), 1164-1176.

[14] E. Berry-Kravis, D. Hessl, S. Coffey, et al., A pilot open label, single dose trial of fenobam in adults with fragile $\mathrm{X}$ syndrome, J Med Genetics 46 (2009), 266-271.

[15] J. Blundell, C.A. Blaiss, M.R. Etherton, et al., Neuroligin-1 deletion results in impaired spatial memory and increased repetitive behavior, J Neurosci 30 (2010), 2115-2129.

[16] C.S. Bonnet, M. Aldred, C. von Ruhland, et al., Defects in cell polarity underlie TSC and ADPKD-associated cystogenesis, Hum Mol Genet 18 (2009), 2166-2176.

[17] C.I. Brannan, A.S. Perkins, K.S. Vogel, et al., Targeted disruption of the neurofibromatosis type-1 gene leads to developmental abnormalities in heart and various neural crestderived tissues, Genes Dev 8 (1994), 1019-1029.

[18] W.J. Brewer, J. Edwards, V. Anderson, et al., Neuropsychological, olfactory, and hygiene deficits in men with negative symptom schizophrenia, Biol Psychiatry 40 (1996), 10211031.

[19] E.C. Budreck and P. Scheiffele, Neuroligin-3 is a neuronal adhesion protein at GABAergic and glutamatergic synapses,
Eur J Neurosci 26 (2007), 1738-1748.

[20] M.G. Butler, Subset of individuals with autism spectrum disorders and extreme macrocephaly associated with germline PTEN tumour suppressor gene mutations, J Med Genet 42 (2005), 318-321.

[21] J.D. Buxbaum, C. Betancur, O. Bozdagi, et al., Optimizing the phenotyping of rodent ASD models: Enrichment analysis of mouse and human neurobiological phenotypes associated with high-risk autism genes identifies morphological, electrophysiological, neurological, and behavioral features. $\mathrm{Mol}$ Autism 3 (2012), 1 [Epub ahead of print].

[22] J.D. Buxbaum, J.M. Silverman, C.J. Smith, et al., Association between a GABRB3 polymorphism and autism, Mol Psychiatry 7 (2002), 311-316.

[23] G. Calfa, A.K. Percy and L. Pozzo-Miller, Experimental models of Rett syndrome based on Mecp2 dysfunction, Exp Biol Med 236 (2011), 3-19.

[24] D.B. Campbell, D. Datta, S.T. Jones, et al., Association of oxytocin receptor (OXTR) gene variants with multiple phenotype domains of autism spectrum disorder, J Neurodev Dis 3 (2011), 101-112.

[25] G. Carboni, P. Tueting, L. Tremolizzo, et al., Enhanced dizocilpine efficacy in heterozygous reeler mice relates to GABA turnover downregulation, Neuropharmacology 46 (2004), 1070-1081.

[26] J.P. Casey, T. Magalhaes, J.M. Conroy, et al., A novel approach of homozygous haplotype sharing identifies candidate genes in autism spectrum disorder, Hum Genet 131 (2012), 565-579.

[27] D. Centonze, S. Rossi, V. Mercaldo, et al., Abnormal striatal GABA transmission in the mouse model for the fragile $\mathrm{X}$ syndrome, Biol Psychiatry 63 (2008), 963-973.

[28] M. Chahrour and H.Y. Zoghbi, The story of Rett syndrome: From clinic to neurobiology, Neuron 56 (2007), 422-437.

[29] H. Chao, H. Chen, R.C. Samaco, et al., Dysfunction in GABA signalling mediates autism-like stereotypies and Rett syndrome phenotypes, Nature 468 (2010), 263-269.

[30] M.A. Cheh, J.H. Millonig, L.M. Roselli, et al., En2 knockout mice display neurobehavioral and neurochemical alterations relevant to autism spectrum disorder, Brain Res 1116 (2006), 166-176.

[31] L. Chen and M. Toth, Fragile X mice develop sensory hyperreactivity to auditory stimuli, Neuroscience 103 (2001), 1043-1050.

[32] R.Z. Chen, S. Akbarian, M. Tudor, et al., Deficiency of methyl-CpG binding protein-2 in CNS neurons results in a Rett-like phenotype in mice. Nature Genet 27 (2001), 327331.

[33] B. Chih, L. Gollan and P. Scheiffele, Alternative splicing controls selective trans-synaptic interactions of the neuroliginneurexin complex, Neuron 51 (2006), 171-178.

[34] J. Choi, S. Kamdar, T. Rahman, et al., ENGRAILED 2 (EN2) genetic and functional analysis , In: Autism Spectrum Disorders - From Genes to Environment, T. Williams, ed., InTech, Croatia, 2011, pp. 3-22.

[35] A.A. Chubykin, D. Atasoy, M.R. Etherton, et al., Activitydependent validation of excitatory versus inhibitory synapses by neuroligin-1 versus neuroligin-2, Neuron 54 (2007), 919931.

[36] K. Cichowski and T. Jacks, NF1 tumor suppressor gene function: narrowing the GAP, Cell 104 (2001), 593-604.

[37] C. Corcoran, A. Whitaker, E. Coleman, et al., Olfactory deficits, cognition and negative symptoms in early onset psychosis, Schizophrenia Res 80 (2005), 283-293. 
[38] R.M. Costa, T. Yang, D.P. Huynh, et al., Learning deficits, but normal development and tumor predisposition in mice lacking exon 23a of Nf1, Nature Genet 27 (2001), 399-405.

[39] R.M. Costa, N.B. Federov, J.H. Kogan, et al., Mechanism for the learning deficits in a mouse model of neurofibromatosis type 1, Nature 415 (2002), 526-530.

[40] A.M. Craig and Y. Kang, Neurexin-neuroligin signaling in synapse development, Curr Op Neurobiol 17 (2007), 43-52.

[41] Y. Cui, R.M. Costa, G.G. Murphy, et al., Neurofibromin regulation of ERK signaling modulates GABA release and learning, Cell 135 (2008), 549-560.

[42] C.T. Culiat, L.J. Stubbs, C.S. Montgomery, et al., Phenotypic consequences of deletion of the gamma 3 , alpha 5 , or beta 3 subunit of the type A gamma-aminobutyric acid receptor in mice, Proc Natl Acad Sci U S A 91 (1994), 2815-2818.

[43] G. Curia, T. Papouin, P. Seguela, et al., Downregulation of tonic GABAergic inhibition in a mouse model of fragile $\mathrm{X}$ syndrome, Cerebral Cortex 19 (2009), 1515-1520.

[44] T. Curran and G. D'Arcangelo, Role of reelin in the control of brain development, Brain Res Brain Res Rev 26 (1998), 285-294.

[45] G. D'Arcangelo, Reelin mouse mutants as models of cortical development disorders, Epilepsy Behav 8 (2006), 81-90.

[46] G. Dawson, Early behavioral intervention, brain plasticity, and the prevention of autism spectrum disorder, Dev Psychopathol 20 (2008), 775-803.

[47] T.M. De Lorey, P. Sahbaie, E. Hashemi, et al., Gabrb3 gene deficient mice exhibit impaired social and exploratory behaviors, deficits in non-selective attention and hypoplasia of cerebellar vermal lobules: a potential model of autism spectrum disorder. Behav Brain Res 187 (2008), 207-220.

[48] F.M. De Vrij, J. Levenga, H.C. van der Linde, et al., Rescue of behavioral phenotype and neuronal protrusion morphology in Fmr1 KO mice, Neurobiol Dis 31 (2008), 127-132.

[49] C. D'Hulst, I. Heulens, J.R. Brouwer, et al., Expression of the GABAergic system in animal models for fragile X syndrome and fragile $\mathrm{X}$ associated tremor/ataxia syndrome (FXTAS), Brain Res 1253 (2009), 176-183.

[50] G. Dölen, E. Osterweil, B.S. Rao, et al., Correction of fragile X syndrome in mice, Neuron 56 (2007), 955-962.

[51] G. Dölen and M.F. Bear, Role for metabotropic glutamate receptor 5 (mGluR5) in the pathogenesis of fragile $\mathrm{X}$ syndrome, J Physiol 586 (2008), 1503-1508.

[52] G. Dölen and M.F. Bear, Fragile x syndrome and autism: from disease model to therapeutic targets, J Neurodev Dis 1 (2009), 133-140.

[53] C.M. Durand, C. Betancur, T.M. Boeckers, et al., Mutations in the gene encoding the synaptic scaffolding protein SHANK3 are associated with autism spectrum disorders, $\mathrm{Na}$ ture Genet 39 (2006), 25-27.

[54] R.P. Ebstein, S. Israel, E. Lerer, et al., Arginine vasopressin and oxytocin modulate human social behavior, Ann NY Acad Sci 1167 (2009), 87-102.

[55] M.J. Eliason, Neurofibromatosis: implications for learning and behavior, J Dev Behav Pediatr 7 (1986), 175-179.

[56] D. Ehninger, S. Han, C. Shilyansky, et al., Reversal of learning deficits in a Tsc2+/- mouse model of tuberous sclerosis, Nature Medicine 14 (2008), 843-848.

[57] J. Feng, R. Schroer, J. Yan, et al., High frequency of neurexin lbeta signal peptide structural variants in patients with autism, Neurosci Lett 409 (2006), 10-13.

[58] J.N. Ferguson, J.M. Aldag, T.R. Insel, et al., Oxytocin in the medial amygdala is essential for social recognition in the mouse, J Neurosci 21 (2001), 8278-8285.
[59] T. Fernandez, T. Morgan, N. Davis, et al., Disruption of Contactin 4 (CNTN4) results in developmental delay and other features of $3 p$ deletion syndrome, Am J Hum Genet 74 (2004), 1286-1293.

[60] S.E. Fisher and C. Scharff, FOXP2 as a molecular window into speech and language, Trends Genet 25 (2009), 166-177.

[61] S.E. Folstein and B. Rosen-Sheidley, Genetics of autism: complex aetiology for a heterogeneous disorder, Nature Rev Genet 2 (2001), 943-955.

[62] E. Förster, A. Tielsch, B. Saum, et al., Reelin, Disabled 1, and beta 1 integrins are required for the formation of the radial glial scaffold in the hippocampus, Proc Natl Acad Sci U S A 99 (2002), 13178-13183.

[63] J. Gauthier, D. Spiegelman, A. Piton, et al., Novel de novo SHANK3 mutation in autistic patients, Am J Med Genet 150B (2009), 421-424.

[64] E. Giacometti, S. Luikenhuis, C. Beard, et al., Partial rescue of MeCP2 deficiency by postnatal activation of MeCP2. Proc Natl Acad Sci U S A 104 (2007), 1931-1936.

[65] G. Gimpl and F. Fahrenholz, The oxytocin receptor system: structure, function, and regulation, Physiol Rev 81 (2001), 629-683.

[66] A. Goffin, L.H. Hoefsloot, E. Bosgoed, et al., PTEN mutation in a family with Cowden syndrome and autism, Am J Med Genet 105 (2001), 521-524.

[67] N. Gogolla, J.J. Leblanc, K.B. Quast, et al., Common circuit defect of excitatory-inhibitory balance in mouse models of autism, J Neurodev Dis 1 (2009), 172-181.

[68] S.M. Goorden, G.M. van der Woerden, L. van den Weerd, et al., Cognitive deficits in mice in the absence of cerebral lesions and seizures, Ann Neurol 62 (2007), 648-655.

[69] M. Groszer, D.A. Keays, R.M. Deacon, et al., Impaired synaptic plasticity and motor learning in mice with a point mutation implicated in human speech deficits, Curr Biol 18 (2008), 354-362.

[70] J. Guy, B. Hendrich, M. Holmes, et al., A mouse Mecp2null mutation causes neurological symptoms that mimic Rett syndrome, Nature Genet 27 (2001), 322-326.

[71] V. Hammond, E. So, J. Gunnersen, et al., positioning of lateborn cortical interneurons is dependent on Reelin but not p35 signaling, J Neurosci 26 (2006), 1646-1655.

[72] A. Hogart, K.N. Leung, N.J. Wang, D.J. Wu, J. Driscoll, R.O. Vallero, et al., Chromosome 15q11-13 duplication syndrome brain reveals epigenetic alterations in gene expression not predicted from copy number, J Med Genet 46 (2009), 86-93.

[73] A. Hogart, R.P. Nagarajan, K.A. Patzel, et al., 15q11-13 GABAA receptor genes are normally biallelically expressed in brain yet are subject to epigenetic dysregulation in autismspectrum disorders, Hum Mol Genet 16 (2007), 691-703.

[74] G.L. Holmes and C.E. Stafstrom, Tuberous sclerosis complex and epilepsy: Recent developments and future challenges, Epilepsia 48 (2007), 617-630.

[75] G.E. Homanics, T.M. DeLorey, L.L. Firestone, et al., Mice devoid of gamma-aminobutyrate type A receptor beta3 subunit have epilepsy, cleft palate, and hypersensitive behavior, Proc Natl Acad Sci U S A 94 (1997), 4143-4148.

[76] M. Hoon, T. Soykan, B. Falkenburger, et al., Neuroligin-4 is localized to glycinergic postsynapses and regulates inhibition in the retina, Proc Natl Acad Sci U S A 108 (2011), 30533058 .

[77] T.R. Insel, A neurobiological basis of social attachment, Am J Psychiatry 154 (1997) 726-735.

[78] T.R. Insel and L.J. Young, Neuropeptides and the evolution of social behavior, Curr Op Neurobiol 10 (2000), 784-789. 
[79] T. Jacks, T.S. Shih, E.M. Schmitt, et al., Tumour predisposition in mice heterozygous for a targeted mutation in Nf1, Nature Genet 7 (1994), 353-361.

[80] S. Jacob, C.W. Brune, C.S. Carter, et al., Association of the oxytocin receptor gene (OXTR) in Caucasian children and adolescents with autism, Neurosci Lett 417 (2007), 6-9.

[81] S. Jacquemont, A. Curie, V. des Portes, et al., Epigenetic modification of the FMR1 gene in fragile X syndrome is associated with differential response to the mGluR5 antagonist AFQ056, Sci Transl Med 3 (2011), 64ra1.

[82] S. Jamain, H. Quach, C. Betancur, et al., Mutations of the $\mathrm{X}$-linked genes encoding neuroligins NLGN3 and NLGN4 are associated with autism, Nature Genet 34 (2003), 27-29.

[83] S. Jamain, K. Radyushkin, K. Hammerschmidt, et al., Reduced social interaction and ultrasonic communication in a mouse model of monogenic heritable autism, Proc Natl Acad Sci U S A 105 (2008), 1710-1715.

[84] Y. Jiang, Y. Pan, L. Zhu, et al., Altered ultrasonic vocalization and impaired learning and memory in Angelman syndrome mouse model with a large maternal deletion from Ube3a to Gabrb3, PLoS One 5 (2010), e12278.

[85] A.L. Joyner, K. Herrup, B.A. Auerbach et al., Subtle cerebellar phenotype in mice homozygous for a targeted deletion of the En-2 homeobox, Science 251 (1991), 1239-1243.

[86] J. Jozwiak, Hamartin and tuberin: working together for tumour suppression, Int J Cancer 118 (2006), 1-5.

[87] T. Kaneko-Goto, S. Yoshihara, H. Miyazaki, et al., BIG2 mediates olfactory axon convergence to target glomeruli, Neuron 57 (2008), 834-846.

[88] T. Kishino, M. Lalande and J. Wagstaff, UBE3A/E6-AP mutations cause Angelman syndrome, Nature Genet 15 (1997), 70-73.

[89] T. Kobayashi, O. Minowa, Y. Sugitani, et al., A germ-line Tsc1 mutation causes tumor development and embryonic lethality that are similar, but not identical to, those caused by Tsc2 mutation in mice, Proc Natl Acad Sci U S A 98 (2001), 8762-8767.

[90] H. Kreienkamp, Scaffolding proteins at the postsynaptic density: shank as the architectural framework, Handb Exp Pharmacol 186 (2008), 365-380.

[91] S. Kurt, S.E. Fisher and G. Ehret, Foxp2 mutations impair auditory-motor association learning, PLoS One 7 (2012), e33130.

[92] M.C. Laarakker, N.R. Reinders, H. Bruining et al., Sexdependent novelty response in neurexin- $1 \alpha$ mutant mice, PLoS One 7 (2012), e31503.

[93] C.S. Lai, S.E. Fisher, J.A. Hurst, et al., A forkhead-domain gene is mutated in a severe speech and language disorder, Nature 413 (2001), 519-523.

[94] C.S. Lai, D. Gerrelli, A.P. Monaco, et al., FOXP2 expression during brain development coincides with adult sites of pathology in a severe speech and language disorder, Brain 126 (2003), 2455-2462.

[95] J.N. Levinson, R. Li, R. Kang, et al., Postsynaptic scaffolding molecules modulate the localization of neuroligins, $\mathrm{Neu}$ roscience 165 (2010), 782-793.

[96] L. Li, D. Cao, H. Kim, et al., Simvastatin enhances learning and memory independent of amyloid load in mice, Ann Neurol 60 (2006), 729-739.

[97] W. Li, Y. Cui, S.A. Kushner, et al., The HMG-CoA reductase inhibitor lovastatin reverses the learning and attention deficits in a mouse model of neurofibromatosis type 1, Curr Biol 15 (2005), 1961-1967.
[98] W.S. Liu, C. Pesold, M.A. Rodriguez, et al., Down-regulation of dendritic spine and glutamic acid decarboxylase 67 expressions in the reelin haploinsufficient heterozygous reeler mouse, Proc Natl Acad Sci U S A 98 (2001), 3477-3482.

[99] V. Louhivuori, A. Vicario, M. Uutela, et al., BDNF and TrkB in neuronal differentiation of Fmr1-knockout mouse, Neurobiol Dis 41 (2011), 469-480.

[100] H.R. Luo, H. Hattori, M.A. Hossain, et al., Akt as a mediator of cell death, Proc Natl Acad Sci U S A 100 (2003), 1171211717.

[101] S. Macrì, F. Biamonte, E. Romano, et al., Perseverative responding and neuroanatomical alterations in adult heterozygous reeler mice are mitigated by neonatal estrogen administration, Psychoneuroendocrinology 35 (2010), 1374-1387.

[102] G.A. Martin, D. Viskochil, G. Bollag, et al., The GAP-related domain of the neurofibromatosis type 1 gene product interacts with ras p21, Cell 63 (1990), 843-849.

[103] T. Marui, O. Hashimoto, E. Nanba, et al., Association between the neurofibromatosis-1 (NF1) locus and autism in the Japanese population, Am J Med Genet 131B (2004), 43-47.

[104] O. Mbarek, S. Marouillat, J. Martineau, et al., Association study of the NF1 gene and autistic disorder, Am J Med Genet 88 (1999) 729-732.

[105] C.H. McNaughton, J. Moon, M.S. Strawderman, et al., Evidence for social anxiety and impaired social cognition in a mouse model of fragile X syndrome, Behav Neuroscience 122 (2008), 293-300.

106] L. Meikle, D.M. Talos, H. Onda, et al., A mouse model of tuberous sclerosis: neuronal loss of Tsc1 causes dysplastic and ectopic neurons, reduced myelination, seizure activity, and limited survival, J Neurosci 27 (2007), 5546-5558.

[107] L. Meikle, K. Pollizzi, A. Egnor, et al., Response of a neuronal model of tuberous sclerosis to mammalian target of rapamycin (mTOR) inhibitors: Effects on mTORC1 and Akt signaling lead to improved survival and function, $J$ Neurosci 28 (2008), 5422-5432.

[108] Y.S. Mineur, F. Sluyter, S. de Wit, et al., Behavioral and neuroanatomical characterization of the Fmr1 knockout mouse, Hippocampus 12 (2002), 39-46.

[109] Y.S. Mineur, L.X. Huynh and W.E. Crusio, Social behavior deficits in the Fmr1 mutant mouse, Behav Brain Res 168 (2006), 172-175.

[110] K. Miura, T. Kishino, E. Li, et al., Neurobehavioral and electroencephalographic abnormalities in Ube3a maternaldeficient mice, Neurobiol Dis 9 (2002), 149-159.

[111] R. Moessner, C.R. Marshall, J.S. Sutcliffe, et al., Contribution of SHANK3 mutations to autism spectrum disorder, Am J Hum Genet 81 (2007), 1289-1297.

[112] J. Moon, A.E. Beaudin, S. Verosky, et al., Attentional dysfunction, impulsivity, and resistance to change in a mouse model of fragile X syndrome, Behav Neurosci 120 (2006), 1367-1379.

[113] D.M. Nielsen, W.J. Derber, D.A. McClellan, et al., Alterations in the auditory startle response in Fmr1 targeted mutant mouse models of fragile X syndrome, Brain Res 927 (2002), 8-17.

[114] K. North, Neurofibromatosis type 1, Am J Hum Genet 97 (2000), 119-127.

[115] P.R. Patrylo, R.A. Browning and S. Cranick, Reeler homozygous mice exhibit enhanced susceptibility to epileptiform activity, Epilepsia 47 (2006), 257-266.

[116] P.H. Patterson, Modeling autistic features in animals, Pediatric Res 69 (2011), 34R-40R. 
[117] J. Peça, C. Feliciano, J.T. Ting, et al., Shank3 mutant mice display autistic-like behaviours and striatal dysfunction, $\mathrm{Na}$ ture 472 (2011), 437-442.

[118] O. Peñagarikano, B. Abrahams, E. Herman, et al., Absence of CNTNAP2 leads to epilepsy, neuronal migration abnormalities, and core autism-related deficits, Cell 147 (2011), 235-246.

[119] S. Pietropaolo, A. Guilleminot, B. Martin, et al., Geneticbackground modulation of core and variable autistic-like symptoms in Fmr1 knock-out mice, PLoS One 6 (2011), e17073.

[120] S. Poliak and E. Peles, The local differentiation of myelinated axons at nodes of Ranvier, Nature Rev Neurosci 4 (2003), 968-980.

[121] S.J. Rogers, and L.A. Vismara, Evidence-based comprehensive treatments for early autism, J Clin Child Adol Psychol 37 (2008), 8-38.

[122] J. Roohi, C. Montagna, D.H. Tegay, et al., Disruption of contactin 4 in three subjects with autism spectrum disorder, J Med Genet 46 (2009), 176-182.

[123] S.E. Rotschafer, M.S. Trujillo, L.E. Dansie, et al., Minocycline treatment reverses ultrasonic vocalization production deficit in a mouse model of Fragile X Syndrome, Brain Res 1439 (2012), 7-14.

[124] M. Sala, D. Braida, D. Lentini, et al., Pharmacologic rescue of impaired cognitive flexibility, social deficits, increased aggression, and seizure susceptibility in oxytocin receptor null mice: A neurobehavioral model of autism, Biol Psychiatry 69 (2011), 875-882.

[125] L. Selby, C. Zhang and Q. Sun, Major defects in neocortical GABAergic inhibitory circuits in mice lacking the fragile $\mathrm{X}$ mental retardation protein, Neurosci Lett 412 (2007), 227232.

[126] M. Shahbazian, J. Young, L. Yuva-Paylor, et al., Mice with truncated $\mathrm{MeCP} 2$ recapitulate many Rett syndrome features and display hyperacetylation of histone H3, Neuron 35 (2002), 243-254.

[127] C. Shilyansky, Y.S. Lee and A.J. Silva, Molecular and cellular mechanisms of learning disabilities: a focus on NF1, Ann Rev Neurosci 33 (2010), 221-243.

[128] C. Shilyansky, K.H. Karlsgodt, D.M. Cummings, et al., Neurofibromin regulates corticostriatal inhibitory networks during working memory performance, Proc Natl Acad Sci U S A 107 (2010), 13141-13146.

[129] W. Shu, J.Y. Cho, Y. Jiang, et al., Altered ultrasonic vocalization in mice with a disruption in the Foxp2 gene, Proc Natl Acad Sci U S A 102 (2005), 9643-9648.

[130] J.L. Silverman, M. Yang, C. Lord, et al., Behavioural phenotyping assays for mouse models of autism, Nature Rev Neurosci 11 (2010), 1-13.

[131] A.J. Silva, P.W. Frankland, Z. Marowitz, et al., A mouse model for the learning and memory deficits associated with neurofibromatosis type I, Nature Genet 15 (1997), 281-284.

[132] S.E. Smith, Y. Zhou, G. Zhang, et al., Increased gene dosage of Ube 3 a results in autism traits and decreased glutamate synaptic transmission in mice, Science Transl Med 3 (2011), 103 ra97.

[133] S.J. Spence and M.T. Schneider, The role of epilepsy and epileptiform EEGs in autism spectrum disorders, Pediatric Res 65 (2009), 599-606.

[134] C.M. Spencer, O. Alekseyenko, E. Serysheva, et al., Altered anxiety-related and social behaviors in the Fmr1 knockout mouse model of fragile X syndrome, Genes Brain Behav 4 (2005), 420-430.
[135] C.M. Spencer, O. Alekseyenko, S.M. Hamilton, et al., Modifying behavioral phenotypes in Fmr1KO mice: Genetic background differences reveal autistic-like responses, Autism Res 4 (2011), 40-56

[136] K.A. Strauss, E.G. Puffenberger, M.J. Huentelman, et al., Recessive symptomatic focal epilepsy and mutant contactinassociated protein-like 2, N Engl J Med 354 (2006), 13701377.

[137] T.C. Südhof, Neuroligins and neurexins link synaptic function to cognitive disease, Nature 455 (2008), 903-911.

[138] Y. Suzuki, H.D. Critchley, A. Rowe, et al., Impaired olfactory identification in Asperger's syndrome, J Neuropsyc Clin Neurosci 15 (2003), 105-107.

[139] P. Szatmari, A.D. Paterson, L. Zwaigenbaum, et al., Mapping autism risk loci using genetic linkage and chromosomal rearrangements, Nature Genet 39 (2007), 319-328.

[140] E. Tabolacci, F. Pirozzi, B. Gomez-Mancilla, et al., The mGluR5 antagonist AFQ056 does not affect methylation and transcription of the mutant FMR1 gene in vitro, BMC Med Genet 13 (2012), 13.

[141] K. Tabuchi, J. Blundell, M.R. Etherton, et al., A neuroligin-3 mutation implicated in autism increases inhibitory synaptic transmission in mice, Science 318 (2007), 71-76.

[142] Y. Takayanagi, M. Yoshida, I.F. Bielsky, et al., Pervasive social deficits, but normal parturition, in oxytocin receptordeficient mice, Proc Natl Acad Sci U S A 102 (2005), 1609616101.

[143] S.F. Tavazoie, V.A. Alvarez, D.A. Ridenour, et al., Regulation of neuronal morphology and function by the tumor suppressors Tsc1 and Tsc2, Nature Neurosci 8 (2005),17271734.

[144] A.M. Thomas, N. Bui, J.R. Perkins, et al., Group I metabotropic glutamate receptor antagonists alter select behaviors in a mouse model for fragile $\mathrm{X}$ syndrome, Psychopharmacology 219 (2012), 47-58.

[145] P.P. Tripathi, P. Sgadò, M. Scali, et al., Increased susceptibility to kainic acid-induced seizures in Engrailed-2 knockout mice. Neuroscience 159 (2009), 842-849.

[146] S. Vernes, D.P. Newbury, B. Abrahams, et al., A functional genetic link between distinct developmental language disorders, N Engl J Med 359 (2008), 2337-2345.

[147] K.A. Waite and C. Eng, Protean PTEN: Form and function, Am J Hum Genet 70 (2002), 829-844.

[148] J.T. Winslow, T.R. Insel, The social deficits of the oxytocin knockout mouse, Neuropeptides 36 (2002), 221-229.

[149] S. Wu, M. Jia, Y. Ruan, et al., Positive association of the oxytocin receptor gene (OXTR) with autism in the Chinese Han population, Biol Psychiatry 58 (2005), 74-77.

[150] O. Yabut, A. Renfro, S. Niu, et al., Abnormal laminar position and dendrite development of interneurons in the reeler forebrain, Brain Res 1140 (2007), 75-83.

[151] Q.J. Yan, M. Rammal, M. Tranfaglia, et al., Suppression of two major Fragile X Syndrome mouse model phenotypes by the mGluR5 antagonist MPEP, Neuropharmacology 49 (2005), 1053-1066

[152] K. Yashiro, T.T. Riday, K.H. Condon, et al., Ube3a is required for experience-dependent maturation of the neocortex, Nature Neurosci 12 (2009), 777-783.

[153] D.M. Young, A.K. Schenk, S. Yang, et al., Altered ultrasonic vocalizations in a tuberous sclerosis mouse model of autism, Proc Natl Acad Sci U S A 107 (2010), 11074-11079.

[154] F. Zalfa, M. Giorgi, B. Primerano, et al., The fragile X syndrome protein FMRP associates with $\mathrm{BC} 1 \mathrm{RNA}$ and regu- 
lates the translation of specific mRNAs at synapses, Cell 112 (2003), 317-327.

[155] L. Zeng, L. Xu, D.H. Gutmann, et al., Rapamycin prevents epilepsy in a mouse model of tuberous sclerosis complex, Ann Neurol 63 (2008), 444-453.

[156] J. Zhou, J. Blundell, S. Ogawa, et al., Pharmacological inhibition of mTORC1 suppresses anatomical, cellular, and behavioral abnormalities in neural-specific Pten knock-out mice, J Neurosci 29 (2009), 1773-1783.

[157] R.T. Zori, D.J. Marsh, G.E. Graham, et al., Germline PTEN mutation in a family with Cowden syndrome and BannayanRiley-Ruvalcaba syndrome, Am J Med Genet 80 (1998), 399402. 


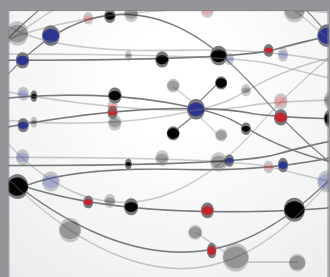

The Scientific World Journal
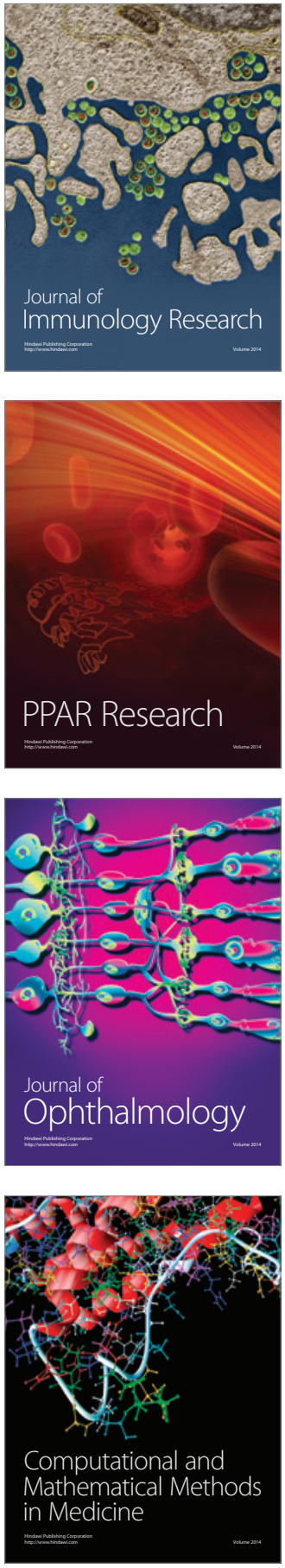

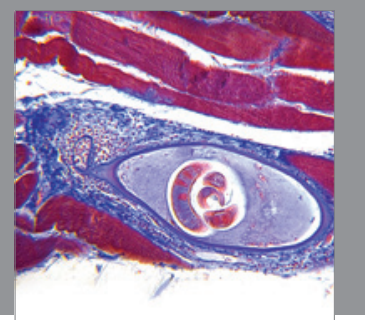

Gastroenterology

Research and Practice
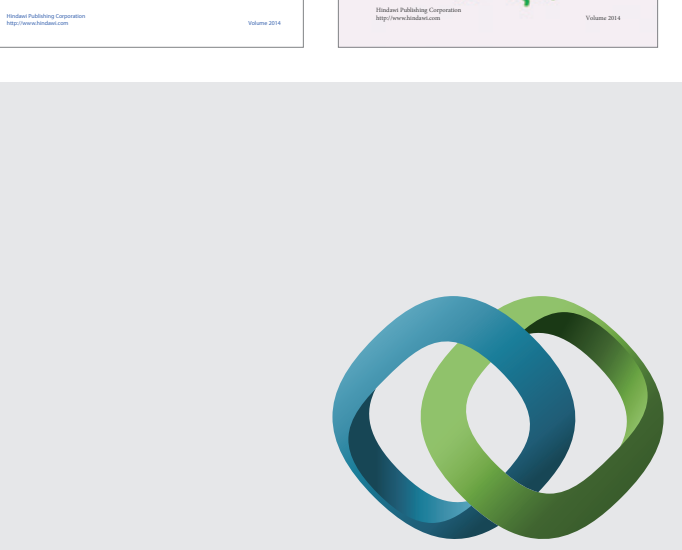

\section{Hindawi}

Submit your manuscripts at

http://www.hindawi.com
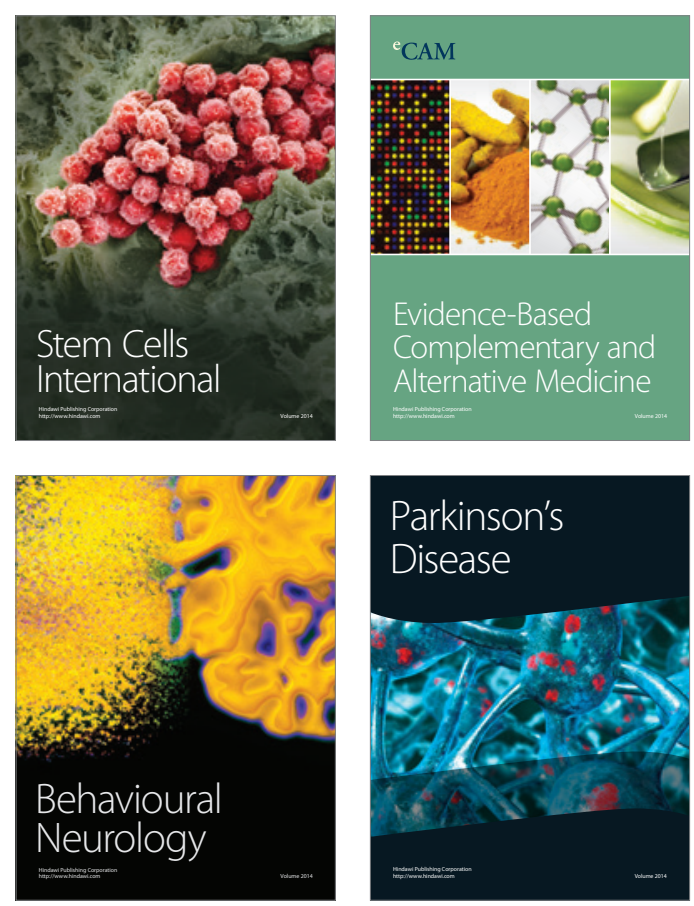

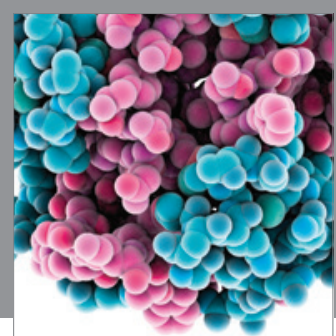

Journal of
Diabetes Research

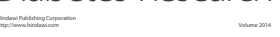

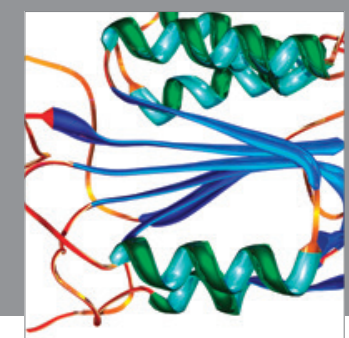

Disease Markers
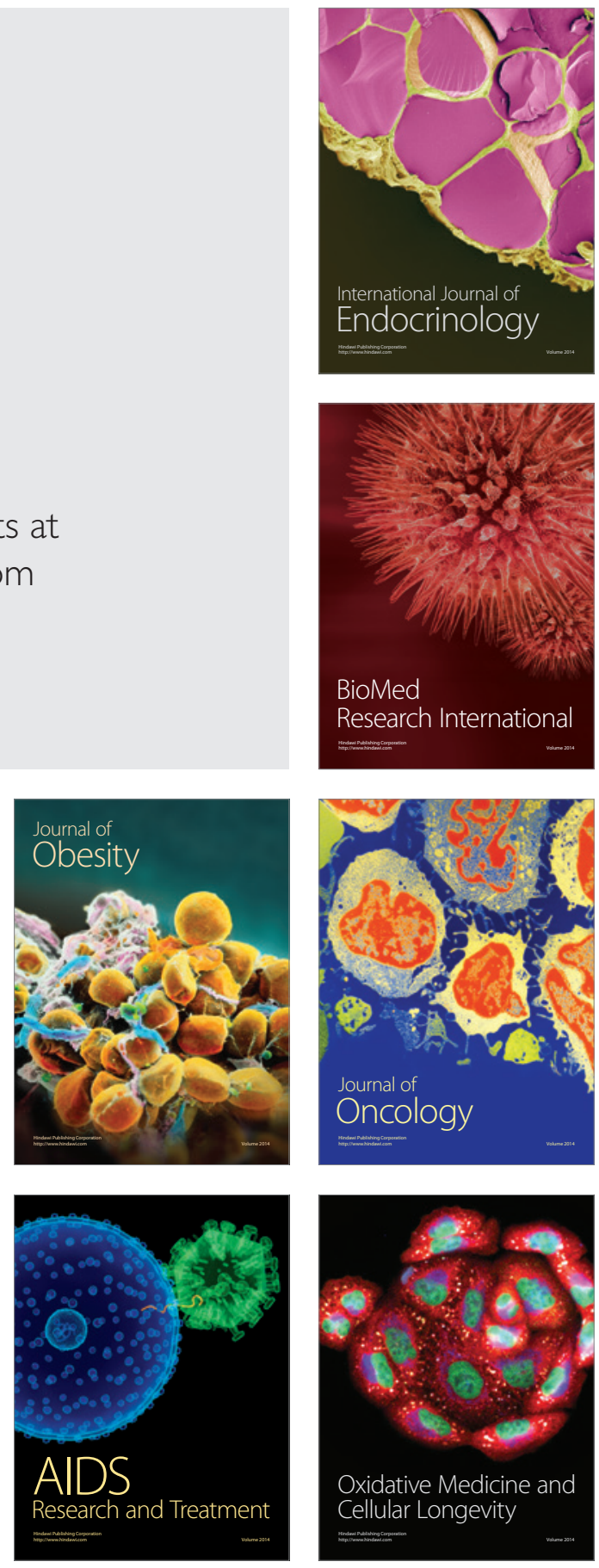